\title{
Overexpression of the Victoriocin Gene in Helminthosporium (Cochliobolus) victoriae Enhances the Antifungal Activity of Culture Filtrates
}

\author{
Patricia B. de Sá, Hua Li, Wendy M. Havens, Mark L. Farman, and Said A. Ghabrial
}

Department of Plant Pathology, University of Kentucky, Lexington 40546-0312.

Current address of P. B. de Sá: United States Department of Agriculture-Animal and Plant Health Inspector Service, PPQ MDL, Beltsville, MD 20705.

Accepted for publication 5 May 2010.

\begin{abstract}
De Sá, P. B., Li, H., Havens, W. M, Farman, M. L., and Ghabrial, S. A. 2010. Overexpression of the victoriocin gene in Helminthosporium victoriae enhances the antifungal activity of culture filtrates. Phytopathology 100:890-896.

We have previously reported the isolation and characterization of the broad-spectrum antifungal protein, victoriocin, from culture filtrates of a virus-infected isolate of the plant-pathogenic fungus Helminthosporium (teleomorph: Cochliobolus) victoriae. We predicted that the $10-\mathrm{kDa}$ mature victoriocin is derived in vivo from a preprotoxin precursor that is processed by a signal peptidase and kexin-like endopeptidase. We also presented evidence that the victoriocin precursor is encoded by a host gene, designated the victoriocin (vin) gene. In the present study, an $H$. victoriae genomic DNA library was constructed in the cosmid vector pMLF-2, and a cosmid clone carrying the vin gene and flanking sequences was isolated and used to generate constructs for transformation of virus-free and virus-infected $H$. victoriae isolates with the vin gene. Culture filtrates of the virus-free vin transformants exhibited high levels of antifungal activity compared with that revealed by the nontransformed

Moreover, transformation of the wild-type virus-infected $H$. victoriae strain with the vin gene resulted in still higher production of victoriocin and higher antifungal activity in the culture filtrates of the vin transformants compared with the virus-infected wild-type strain. As previously predicted, the presence in the vin transformants of the preprovictoriocin and its post-translationally generated products, the provictoriocin and the mature victoriocin, was clearly demonstrated. Processing of the victoriocin preprotoxin requires eukaryotic host factors because no processing occurred in an in vitro translation system or in bacteria. It is of interest that some of the virus-free isolates transformed with the vin gene exhibited some features of the virus-induced disease phenotype, including moderate stunting and sectoring. Present data suggests that victoriocin may play an indirect role in disease development. Taken together, these results indicate that victoriocin is the primary protein responsible for the antifungal activity in culture filtrates of virus-infected $H$. victoriae isolates and that virus infection upregulates the expression of victoriocin. Overproduction of victoriocin may give the slower-growing virusinfected fungal strains some competitive advantage by inhibiting the growth of other fungi.
\end{abstract} virus-free wild-type strain, which exhibited little or no antifungal activity.
Two isometric double-stranded (ds)RNA viruses, the totivirus Helminthosporium victoriae virus $190 \mathrm{~S}$ (HvV190S) and the chrysovirus Helminthosporium victoriae virus $145 \mathrm{~S}$ (HvV145S), are associated with the transmissible disease of $H$. victoriae (teleomorph: Cochliobolus victoriae), the causal agent of Victoria blight of oat $(5,8)$. Diseased $H$. victoriae isolates have reduced growth, excessive sectoring, aerial mycelial collapse, and generalized lysis $(5-8,11)$. Culture filtrates of virus-infected but not virus-free isolates exhibit broad-spectrum antifungal activity (2). De Sá et al. (2) described the isolation and characterization of a broad-spectrum antifungal protein of $\approx 10 \mathrm{kDa}$, designated victoriocin, which was secreted by virus-infected isolates of $H$. victoriae. Victoriocin, like several other antifungal proteins, including the killer toxins of yeasts and smuts, was predicted, based on its structure, to be expressed in vivo as a preprotoxin precursor consisting of a hydrophobic N-terminal secretion signal, followed by a pro-region and terminating in a classical Kex $2 p$ endopeptidase cleavage site that generates the $\mathrm{N}$ terminus of the mature victoriocin. The endogenous gene encoding the victoriocin precursor (preprovictoriocin), designated the victoriocin (vin)

Corresponding author: S. A. Ghabrial; E-mail address: saghab00@email.uky.edu

doi:10.1094/PHYTO-100-9-0890

(c) 2010 The American Phytopathological Society gene, was isolated and characterized (2, this study). Because culture filtrates from virus-free fungal isolates exhibit little or no antifungal activity, it was concluded that virus infection induces overexpression of the vin gene. This study was undertaken to determine whether overexpression of the vin gene in a virus-free fungal isolate would enhance the antifungal activity to higher levels comparable with those of virus-infected isolates and to document the occurrence in vivo of the predicted victoriocin precursors.

\section{MATERIALS AND METHODS}

Fungal and bacterial strains. The $H$. victoriae virus-free and virus-infected strains, B-2ss (American Type Culture Collection [ATCC] 42020) and A-9 (ATCC 42018), respectively, were previously described (2,7). Penicillium chrysogenum (ATCC 9480) was used in the antifungal activity "well assays", as previously described (2).

Escherichia coli strain DH5 $\alpha$ was used as the host strain for cloning of polymerase chain reaction (PCR)-amplified fragments in pGEM-T-Easy (Promega Corp., Madison, WI) and for cloning and propagation of the cosmid vector pMLF2 (1), the bacterial protein expression vector pET-22b(+) (Novagen-EMD, San Diego, CA) and of the fungal expression vector pCB1004 (15). E. coli strain BL21(DE3)plysS (Novagen-EMD) was used for expression of recombinant proteins from $\mathrm{pET}-22 \mathrm{~b}(+)$. 
Constructs for victoriocin expression in $\boldsymbol{E}$. coli. A cDNA clone containing the entire coding region of the victoriocin precursor $(20 \mathrm{kDa})$ was recovered from a cDNA library of $H$. victoriae strain A9 $(2,14)$ and used as a template for PCR amplification with DyNAzyme DNA polymerase (Finnzymes Inc., Woburn, MA) to generate constructs for expression of victoriocin in the bacterial expression vector pET-22b(+). To generate the construct pET-victoriocin, forward and reverse primers (5'-GCGCTGGCCATGGATATGAACTTTGTCTATTC$3^{\prime}$ and $5^{\prime}$-ATATAATTGCGGCCGCTCAGCAGCCACAGCCAC$3^{\prime}$, respectively) were designed with restriction enzyme sites (underlined) for insertion of the coding region of the victoriocin precursor within the NcoI and NotI restriction sites of pET$22 \mathrm{~b}(+)$, thus allowing for the addition of an $\mathrm{N}$-terminal pelB leader sequence but not for a histidine tag at the $C$ terminus of the bacterially expressed protein. The PCR product was gel purified, digested with $N c o I$ and NotI, and ligated into a similarly digested vector.

The plasmid pET-victoriocin and the vector pET-22b(+) were transformed into E. coli strain BL21(DE3)pLysS and the bacterial cultures were grown in Luria-Bertani (LB) broth amended with chloramphenicol $(50 \mu \mathrm{g} / \mathrm{ml})$ and ampicillin $(50 \mu \mathrm{g} / \mathrm{ml})$ to a density of absorbance at $600 \mathrm{~nm}=0.4$ and the cultures were induced with $1.0 \mathrm{mM}$ isopropyl-1-thio- $\beta$-D-galactopyranoside (IPTG). Induced and noninduced bacterial cultures were grown at $37^{\circ} \mathrm{C}$, and samples were collected before induction and $3 \mathrm{~h}$ postinduction. Cells were collected by centrifugation at $10,000 \times$ $g$ for $10 \mathrm{~min}$, frozen overnight, and resuspended in Bug Buster reagent with added Benzonase (Novagen-EMD) for extraction of proteins from soluble and insoluble fractions according to manufacturer's instructions.

Aliquots of total cell extracts, soluble and insoluble fractions, and culture media were analyzed by electrophoresis on $15 \%$ sodium dodecyl sulfate (SDS) polyacrylamide gels followed by staining in Coomassie brilliant blue or subjected to western blot analysis using the victoriocin-specific antiserum AS-P10 (2).

In vitro transcription and translation of cloned vin cDNA. The TNT T7 Quick coupled transcription and translation system (Promega Corp.) was used according to the manufacturer's instructions to assess the expression of cloned vin cDNA. The recombinant plasmid pET-victoriocin and the vector pET-22b(+) $(\approx 1 \mu \mathrm{g}$ each) were added to the transcription and translation reaction mix in the presence of $\left[{ }^{35} \mathrm{~S}\right]$ methionine. A plasmid encoding luciferase, which was included in the kit, was used as a positive control reaction and a reaction mix without added DNA was used as a negative control. The translation products were separated by SDS-polyacrylamide gel electrophoresis (PAGE) on $15 \%$ polyacrylamide gels, stained in Coomassie brilliant blue (R250), and dried. The dried gel was then exposed to a phosphorimager screen and the images were visualized with a PhosphorImager 445 SI system and analyzed with the ImageQuant 4.1 software program system (Amersham Biosciences, Piscataway, $\mathrm{NJ})$.

Construction of $\boldsymbol{H}$. victoriae genomic DNA library. An ordered genomic DNA library of $H$. victoriae strain A-9 was constructed in the cosmid vector pMLF2 (1) essentially as previously described $(1,4,12)$. Strain A-9 was grown in Czapek-Dox (CZ) broth minimal medium in 1-liter flasks under agitation for $72 \mathrm{~h}$ at $23^{\circ} \mathrm{C}$. The mycelium was collected by filtering through Miracloth (Calbiochem, San Diego, CA), freeze dried, and then pulverized in liquid nitrogen. DNA was extracted from mycelium using lysis buffer $(50 \mathrm{mM}$ Tris- $\mathrm{HCl}, \mathrm{pH} 8.0$, containing $50 \mathrm{mM}$ EDTA, pH 8.0, $0.5 \mathrm{M} \mathrm{NaCl}$, and $1 \%$ SDS) that was heated to $65^{\circ} \mathrm{C}$. The slurry was then mixed with an equal volume of phenol/ chloroform/isoamyl alcohol (25:24:1) and the DNA was precipitated with isopropanol, spooled onto a glass rod, washed with $70 \%$ ethanol, air dried, and resuspended in Tris-EDTA buffer (10 mM Tris-HCl, pH 8.0, containing $0.1 \mathrm{mM}$ EDTA). High molecular weight DNA ( $>200 \mathrm{Kbp}$ ) was partially digested with $\mathrm{MboI}$ and then size fractionated on a continuous sucrose gradient (10 to $40 \%$ ) by centrifugation at $28,000 \times g$ for $20 \mathrm{~h}$ at $20^{\circ} \mathrm{C}$. Gradient fractions were collected and aliquots were analyzed by CHEF electrophoresis (CHEF-DRII; Bio-Rad Laboratories, Hercules, CA) to identify those containing genomic DNA fragments of 30 to $45 \mathrm{kbp}$. DNA was precipitated from the relevant fractions and ligated to BamHI-digested pMLF2. The ligation reaction was packaged using Giga Pack III Gold Packaging Extract (Stratagene, La Jolla, CA), and E. coli DH5 $\alpha$ cells were transfected with the packaged ligation reaction. Colonies were transferred to 384-well plates (Nalge Nunc International Corp., Rochester, NY) including $70 \mu \mathrm{l}$ of LB containing $10 \%$ freezer medium (16). The plates were then incubated overnight at $37^{\circ} \mathrm{C}$ and a 384-pin replicator (Nalge Nunc International Corp., Rochester, NY) was used to array colonies onto replicate Pall Biodyne B membranes (Nalge Nunc International Corp.) placed on LB-ampicillin $(100 \mu \mathrm{g} / \mathrm{ml})$ plates. The colonies were grown at $37^{\circ} \mathrm{C}$ for $12 \mathrm{~h}$ and then lysed to release DNA onto the membranes following a previously described protocol (4). The membranes were then hybridized overnight at $42^{\circ} \mathrm{C}$ with a denatured $[\alpha$ ${ }^{32} \mathrm{P}$ ]dCTP-labeled vin probe (2). The hybridized membranes were washed in $2 \times \operatorname{SSPE}(0.3 \mathrm{M} \mathrm{NaCl} ; 20 \mathrm{mM} \mathrm{NaPO} 4 ; 2 \mathrm{mM}$ EDTA, $\mathrm{pH} 7.7$ ) at $42^{\circ} \mathrm{C}$ for $10 \mathrm{~min}, 2 \times \mathrm{SSPE}$ at $50^{\circ} \mathrm{C}$ for $15 \mathrm{~min}$, followed by a wash in $0.1 \times$ SSPE containing $0.1 \%$ SDS for $15 \mathrm{~min}$ at $50^{\circ} \mathrm{C}$. The membranes were exposed to photographic films that were matched to the 384-well plates and positive clones were further selected by Southern hybridization analysis of purified DNAs (2).

Constructs for victoriocin overexpression in $\mathrm{H}$. victoriae. A cosmid clone containing the vin gene (pMLF-L5B), as verified by Southern blot analysis, was used to generate constructs in the fungal transformation vector pCB1004 for overexpression of the vin gene in $H$. victoriae. The pMLF-L5B cosmid clone was digested with BamHI and NotI and the digestion products were separated by electrophoresis on $0.7 \%$ agarose followed by Southern blot analysis to identify a DNA fragment containing the vin gene. A positively identified fragment was gel purified and ligated into the pCB1004 transformation vector that was previously digested with BamHI and Not I to generate the plasmid construct pCB-6. The construct pCB-6 was digested with SnaBI and then with NotI to generate a SnaBI-NotI fragment that was subcloned into pCB1004 predigested with NotI and EcoRV to create the construct pCB-SnaBI/NotI (Fig. 1). Deletion derivatives of pCB-6 were generated by separate restriction enzyme digestions with ClaI, SmaI, and EcoRI and religation of pCB-6, and the resulting constructs were designated pCB-ClaI, pCBSmaI, and pCB-EcoRI (Fig. 1). All constructs were sequenced using M13 forward and reverse universal primers and two genespecific primers, GSP1-F (5'-CTGGTGCTGGAGGAACTGAG$3^{\prime}$ ) and GSP5-R (5'-TAGACAGAAGCTTCATTTTGG-3'), to verify the presence of the vin gene. Two additional primers were designed to identify sequences $5^{\prime}$ and $3^{\prime}$ to the vin gene: $5^{\prime} \mathrm{VIN}-\mathrm{F}$ (5'-TTCCTCCATTGATTGCTATCTTCG-3') and VIN3'-R (5'CTTCTTACACGGCTCCTTTATTC-3').

Transformation of $\mathrm{H}$. victoriae with vin constructs. Protoplasts from the virus-free $H$. victoriae strain B-2ss were prepared from mycelium according to the method described by Yoder (17), except that Glucanex (Sigma-Aldrich, St. Louis) at $10 \mathrm{mg} / \mathrm{ml}$ was used in place of Novozyme 234 in the enzyme osmoticum solution. In all, $\approx 5 \times 10^{7}$ protoplasts were transformed with the four constructs pCB-ClaI, pCB-SnaBI/NotI, pCB-SmaI, and pCB-EcoRI as well as with the transformation vector pCB1004 alone, as previously described (18). The transformants were recovered in regeneration medium $(10 \mathrm{ml}$ of $0.1 \%$ yeast extract, $0.1 \%$ casein hydrolyzate, $1 \mathrm{M}$ sucrose, and $1.75 \%$ agar) containing hygromycin B $(50 \mu \mathrm{g} / \mathrm{ml})$. To ensure nuclear homogeneity, transformed isolates were purified by two rounds of single 
conidia isolations and grown on potato dextrose agar medium containing $0.5 \%(\mathrm{wt} / \mathrm{vol})$ yeast extract and hygromycin B $(50 \mu \mathrm{g} / \mathrm{ml})$ for 1 to 2 weeks. The virus-infected $H$. victoriae strain A-9 was also transformed with the pCB-ClaI construct as described above. Expression of victoriocin was examined by northern and western blot analysis, and antifungal activity of culture filtrates was verified by the well assay (2).

Northern and western blot analysis. Total RNA and total protein were extracted from mycelium of $H$. victoriae grown in $\mathrm{CZ}$ medium and subjected to northern and western blot analyses, respectively. Total RNA was prepared by pulverizing $1 \mathrm{~g}$ of mycelium in liquid nitrogen and adding to the powdered mycelium $10 \mathrm{ml}$ of RNA extraction buffer $(0.2 \mathrm{M} \mathrm{LiCl} ; 0.2 \mathrm{M}$ Tris-HCl, $\mathrm{pH}$ 8.0; 0.02 M EDTA; and 2\% SDS); then, Tris-equilibrated phenol heated to $80^{\circ} \mathrm{C}$ was added at a ratio of $1: 1$. The resulting slurry was mixed for $5 \mathrm{~min}$, then centrifuged $(15,300 \times g, 10 \mathrm{~min})$, and $4 \mathrm{M} \mathrm{LiCl}$ was added to the upper phase. Isopropanol and $3 \mathrm{M}$ sodium acetate were used in the final RNA precipitation step. The RNA was glyoxal denatured and fractionated by electrophoresis on $0.8 \%$ agarose gels in $10 \mathrm{mM}$ phosphate buffer, $\mathrm{pH} 6.3$, as previously described (12). The RNA was transferred to Hybond X-L membranes by semi-dry transfer using the PowerPak 200 (Bio-Rad Laboratories) transfer apparatus and were UV crosslinked. The membranes were hybridized overnight at $42^{\circ} \mathrm{C}$ with the denatured vin probe in hybridization solution (50\% formamide; $5 \times$ Denhardt's solution; $5 \times$ SSC; $0.5 \%$ [wt/vol] SDS; and boiled, sheared salmon sperm DNA at $100 \mu \mathrm{g} / \mathrm{ml})$. The membranes were washed using high-stringency conditions $(2 \times \mathrm{SSC}$ and $0.1 \%$ SDS at room temperature for $10 \mathrm{~min}, 1 \times \mathrm{SSC}$ and $0.1 \%$
SDS at $65^{\circ} \mathrm{C}$ for $15 \mathrm{~min}$, and $0.1 \times \mathrm{SSC}$ and $0.1 \% \mathrm{SDS}$ at $65^{\circ} \mathrm{C}$ for $10 \mathrm{~min}$ ) and the membranes were then air dried, exposed to a phosphorimager screen, and visualized with the PhosphorImager 445 SI system.

For analysis of protein expression, proteins were extracted from fungal mycelium with a modification of the procedure of Osherov and May (10). Lyophilized mycelium (10 mg) was ground in liquid nitrogen and $0.5 \mathrm{ml}$ of $10 \%$ trichloroacetic acid was added to the powdered mycelium; the resultant slurry was mixed by vortexing and incubated at room temperature for $5 \mathrm{~min}$. The slurry was centrifuged $(12,000 \times g$ for $5 \mathrm{~min})$ and the pellet was washed three times with a solution of $90 \%$ acetone with $20 \mathrm{mM} \mathrm{HCl}$ and air dried. The pellet was resuspended in $0.2 \mathrm{ml}$ of sample buffer (1\% SDS, $9 \mathrm{M}$ urea, $25 \mathrm{mM}$ Tris- $\mathrm{HCl}, 1 \mathrm{mM}$ EDTA, and $0.7 \mathrm{M} \beta$-mercaptoethanol) and samples were loaded onto $15 \%$ SDS-polyacrylamide gels for electrophoresis and western blot analysis. Proteins resolved by electrophoresis were transferred to polyvinylidene difluoride membranes for western blotting and probed with the victoriocin-specific antiserum AS-P10 (2).

Sequencing and sequence analysis. Sequencing of constructs for protein expression, fungal transformation, and cosmid DNA was performed by automated DNA dideoxy-termination sequencing using the Big Dye terminator sequencing kit (Applied Biosystems Inc., Foster City, CA) on an ABI600 automated sequencer using M13 forward and reverse primers and genespecific primers. The sequences were assembled and analyzed using programs in the University of Wisconsin GCG software package (3) and DNA Strider (9).
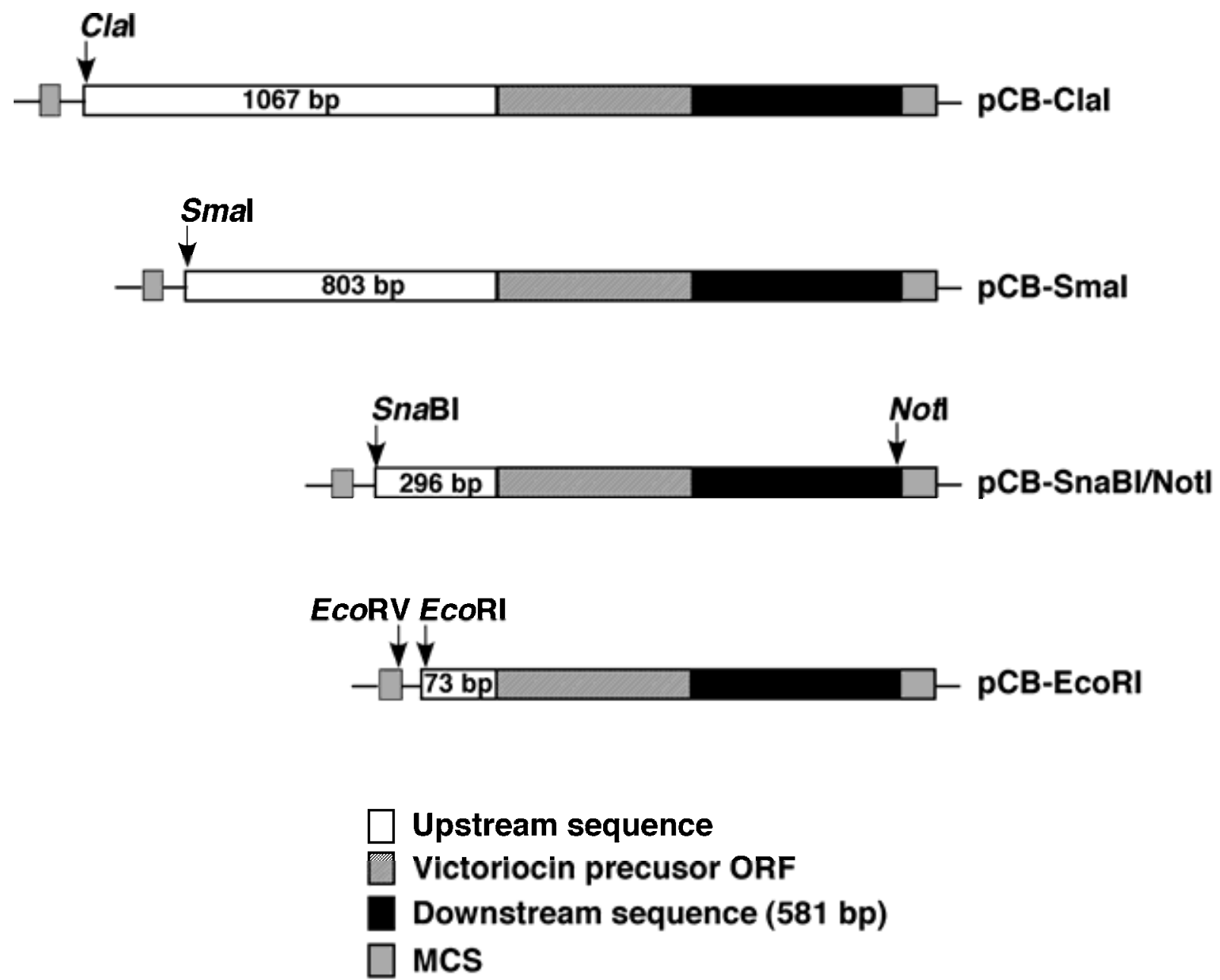

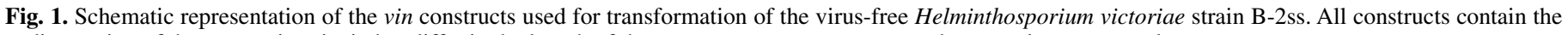
coding region of the preprovictoriocin but differ in the length of the upstream sequences presumed to contain promoter elements. 


\section{RESULTS}

Expression of victoriocin precursor in $\boldsymbol{E}$. coli. We generated the construct pET-victoriocin in the bacterial vector pET-22b(+) for expression of the victoriocin precursor in E. coli strain BL21 (DE3)plysS, and analyzed the products synthesized by western blotting using the victoriocin-specific antiserum AS-P10 (2). A protein band of $\approx 25 \mathrm{kDa}$ was detected in the soluble fraction of cultures of BL21-(DE3)pLysS transformed with the pET-victoriocin plasmid and grown at $37^{\circ} \mathrm{C}$ for $3 \mathrm{~h}$ following induction with $1 \mathrm{mM}$ IPTG (Fig. 2A, lane 1). No such band was detected in the soluble fraction of the noninduced cultures transformed with the pET-victoriocin (Fig. 2A, lane 2). Furthermore, the band corresponding to the victoriocin precursor was also absent in the soluble fraction of induced or noninduced cultures of BL21(DE3)pLysS transformed with the control pET-22b(+) (Fig. $2 \mathrm{~A}$, lanes 3 and 4 , respectively).

In vitro transcription and translation of cloned vin cDNA. TNT coupled in vitro transcription and translation of the construct pET-victoriocin produced a protein band of $\approx 25 \mathrm{kDa}$ (Fig. 2B, lanes 1 and 2), which was absent as a translation product when pET-22b(+) DNA or the luciferase DNA was added, or in reactions with no added DNA (Fig. 2B, lanes 3 and 4, respectively). The anomalous behavior of the victoriocin precursor (with calculated molecular mass of $\approx 20 \mathrm{kDa}$ ) on SDS-PAGE is probably is due to its cysteine-rich nature and high stability (2).

Construction of $\boldsymbol{H}$. victoriae genomic library and vin fungal transformation vectors. The $H$. victoriae genomic DNA library had a titer of $3.2 \times 10^{5} \mathrm{CFU} / \mu \mathrm{g}$ of ligation mixture and an average insert size of $40 \mathrm{kbp}$. In total, 8,448 clones were screened, and one cosmid clone (pMLF-L5B) was positive for the vin gene as indicated by Southern hybridization analysis. The pMLF-L5B cosmid clone was used to generate four constructs in the fungal transformation vector pCB1004 (see Materials and Methods). The construct pCB-ClaI was the largest of the four constructs and was completely sequenced. Sequence analysis indicated that the pCBClaI plasmid has an insert of 2,205 bp of $\mathrm{H}$. victoriae genomic

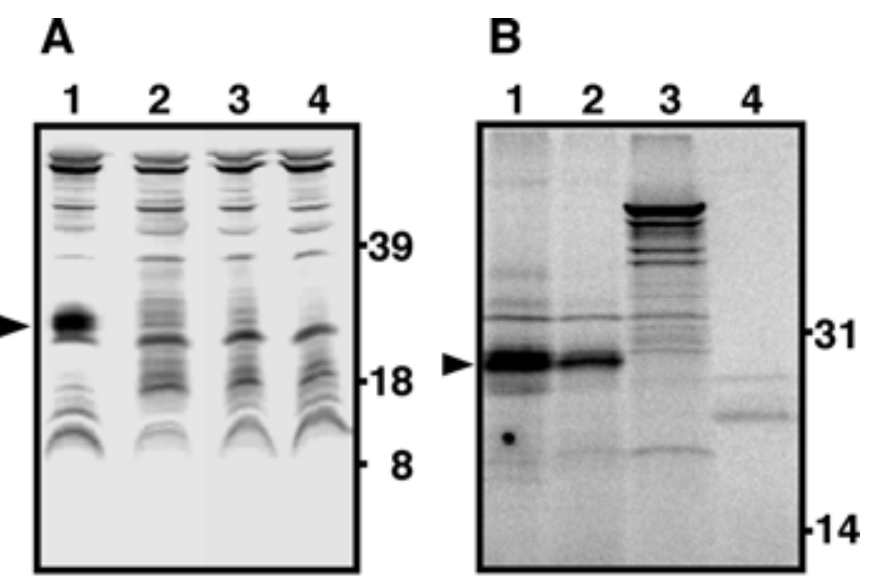

Fig. 2. Bacterial expression and in vitro coupled transcription and translation of the victoriocin precursor. A, Western blot analysis of expression products of preprovictoriocin in induced and noninduced cultures of Escherichia coli strain BL21(DE3)plysS transformed with the pET-victoriocin plasmid (lanes 1 and 2, respectively). Lanes 3 and 4, induced and noninduced cultures of BL21(DE3)pLysS transformed with the control plasmid pET-22b(+). B, Analysis of in vitro translation products of victoriocin precursor coding sequences by sodium dodecyl sulfate polyacrylamide gel electrophoresis on an $8 \%$ polyacrylamide gel and autoradiography. Recombinant plasmid pETvictoriocin of cloned vin cDNA was translated in vitro using the TNT T7 coupled transcription and translation system in the presence of $\left[{ }^{35} \mathrm{~S}\right] \mathrm{methio}-$ nine (lanes 1 and 2$\}$. In vitro translation products of the control pET-22b(+) and luciferase coding sequences are shown in lanes 3 and 4, respectively. Position of the victoriocin precursor is indicated by an arrowhead to the left of the panels and the migration of standard proteins with known molecular masses is shown to the right.
DNA sequences that included the vin open reading frame (ORF), sequences of 1,067 bp upstream of the ATG initiation codon, and sequences of $587 \mathrm{bp}$ downstream of the TGA terminator codon (Fig. 1). As deduced from the sequence of the pCB-ClaI construct and verified by sequencing, all three of the other constructs contain the vin ORF and $587 \mathrm{bp}$ of sequence downstream of the vin ORF. The lengths of the sequences upstream of the vin ORF, which presumably contain putative promoter sequences, were $1,067,803,296$, and 73 bp in clones pCB-ClaI, pCB-SnaBI/NotI, pCB-SmaI, and pCB-EcoRI, respectively (Fig. 1). The nucleotide sequence pCB-ClaI clone has been deposited in GenBank under accession number EF587239.

Analysis of vin transformants. Expression of the vin gene and processing of the preprovictoriocin were analyzed in the virusfree $H$. victoriae isolate $\mathrm{B}-2 \mathrm{ss}$ transformed with $\mathrm{pCB} 1004$ alone (vector) as well as with four vin constructs. Western blot analysis, using an antiserum specific to victoriocin (AS-P10), showed that transformants with constructs pCB-ClaI, pCB-SmaI, and pCBSnaBI/NotI (transformant SnaB1) accumulated higher levels of preprovictoriocin $(\mathrm{ppV})$, provictoriocin $(\mathrm{pV})$ and victoriocin $(\mathrm{V})$ than transformants with construct pCB-EcoRI or with the empty vector (Fig. 3A). Northern hybridization results, using a vin
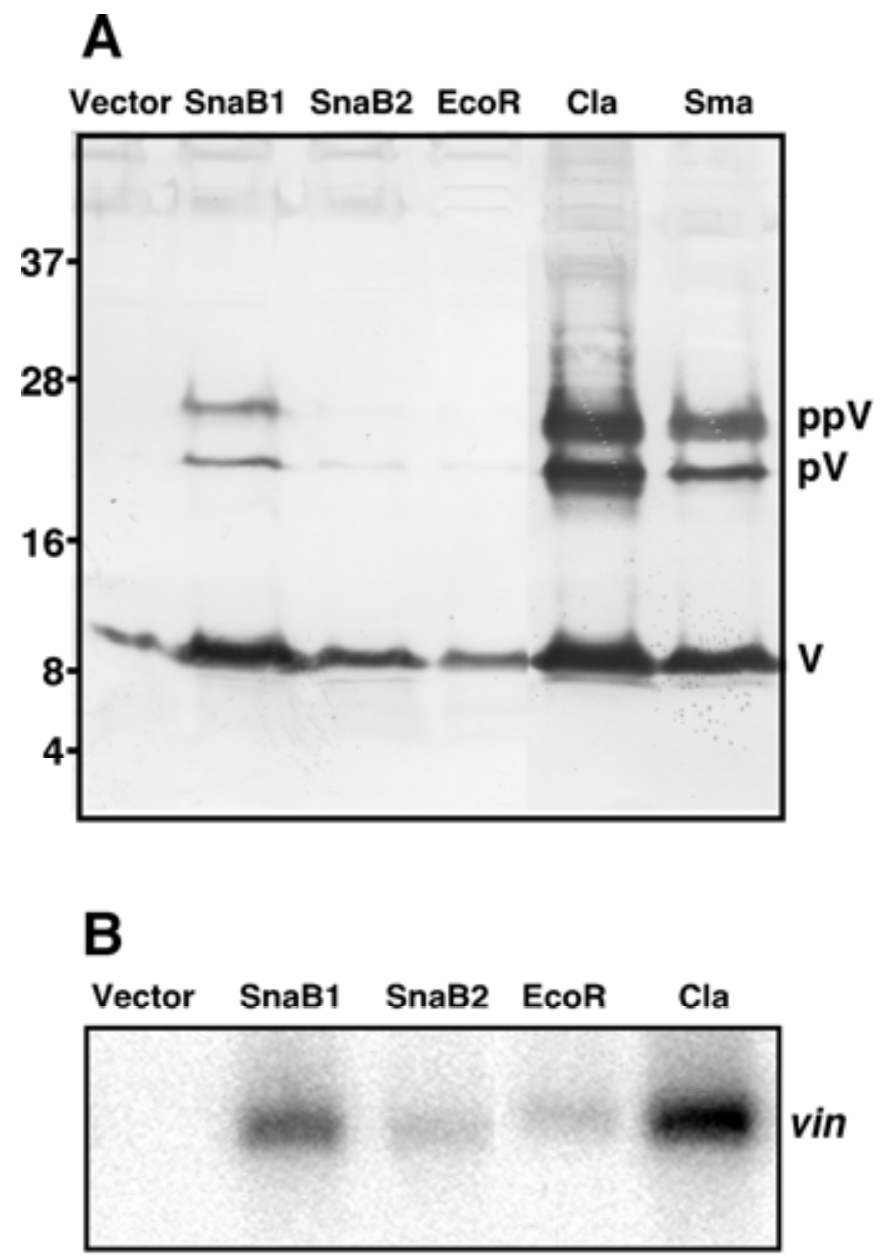

Fig. 3. Analysis of the vin transformants. A, Western blot analysis of proteins extracted from a virus-free Helminthosporium victoriae isolate transformed with the vin constructs pCB-SnaBI/NotI (lanes SnaB1 and SnaB2), pCBEcoRI (lane EcoR), pCB-ClaI (lane Cla), pCB-SmaI (lane Sma), and empty vector (pCB1004; lane vector). $\mathrm{ppV}$, preprovictoriocin; $\mathrm{pV}$, provictoriocin; and $\mathrm{V}$, mature victoriocin. See Figure 1 for diagrams of the vin constructs. B, Northern hybridization analysis of RNA extracts from the same transformants used for Western blotting analysis, including transformants pCB-SnaBI/NotI (lanes SnaB1 and SnaB2), pCB-EcoRI (lane EcoR), pCB-ClaI (lane Cla), and empty vector (pCB1004; lane vector) (a low level of the vin transcript could be observed after extended exposure). 
probe, were consistent with the victoriocin western results (Fig. $3 \mathrm{~B})$. Thus, the length of the sequence upstream of the vin ORF in the various constructs appears to correlate with the victoriocin expression level. Interestingly, the antifungal activity of the

TABLE 1. Diameter of inhibition zone

\begin{tabular}{lccc}
\hline & \multicolumn{3}{c}{ Diameter $(\mathrm{mm})$} \\
\cline { 2 - 4 } Transformant & $24 \mathrm{~h}$ & $48 \mathrm{~h}$ & $72 \mathrm{~h}$ \\
\hline A-9a & 20 & 15 & 13 \\
A-T1 & 25 & 18 & 16 \\
A-T2 & 24 & 17 & 15 \\
A-T3 & 26 & 17 & 15 \\
A-T4 & 28 & 18 & 17 \\
A-T5 & 24 & 16 & 14 \\
A-T6 & 26 & 17 & 16 \\
A-T7 & 26 & 17 & 16 \\
B-2b & 0 & 0 & 0 \\
B-T1 & 14 & 10 & 6 \\
B-T2 & 10 & 11 & 0 \\
B-T3 & 17 & 0 & 6 \\
B-T4 & 6 & 0 & 0 \\
B-T5 & 6 & 12 & 11 \\
B-T6 & 19 & 12 & 10 \\
B-T12 & 15 & 12 \\
B-T18 & 20 & 10 & 9 \\
B-T20 & 20 & 16 &
\end{tabular}

a Wild-type virus-infected Helminthosporium victoriae isolate A-9 and its vin transformants A-T1 to A-T7.

${ }^{\mathrm{b}}$ Wild-type virus free isolate B-2ss and its vin transformants B-T1 to B-T6 and B-T12, B-T18, and B-T20. culture filtrates of the vin transformants also correlated well with the western and northern analyses (data not shown). Although the antifungal activity of some the vin transformants (transformed with construct $\mathrm{pBC}-\mathrm{ClaI}$ ) was as high as that of culture filtrates of the virus-infected strain A-9, many of the transformants showed lower activity (Table 1).

The colony morphology of the vector control (Fig. 4, vector) was indistinguishable from that of the wild-type B-2ss strain. On the other hand, the vin transformants, with the exception of the pCB-EcoRI transformants, showed reduced growth and sectoring (Fig. 4). Although the reduction in growth and sectoring represent features reminiscent of disease symptoms in virus-infected isolates, the latter usually exhibit more severe stunting, aerial mycelium collapse, and excessive sectoring (Fig. 4, isolate A-9).

Transformation of a virus-infected isolate with the vin constructs. It was of interest to determine whether overproduction of victoriocin in a virus-infected isolate would further enhance the antifungal activity of its culture filtrate because the antifungal activity of culture filtrates from the wild-type virusinfected isolate was still higher than most of virus-free transformants with the vin gene (Table 1). For this purpose, isolate A-9 was transformed with the pCB-ClaI construct and victoriocin production and antifungal activity were monitored using western blot analysis and the well assay. The results showed that victoriocin accumulated to higher levels in the A-9 transformants compared with the wild-type strain (Fig. 5). Interestingly, the antifungal activity of the A-9 vin transformants was markedly higher than that of the wild-type A-9 strain and the virus-free strain overexpressing the vin gene (Table 1).

\section{Empty vector}
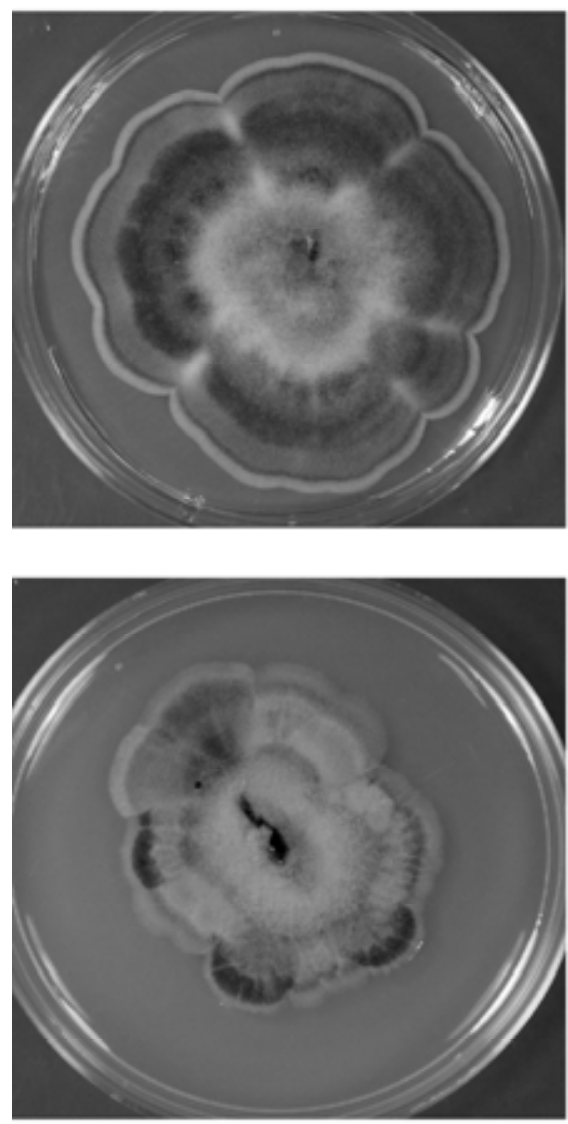

ClaBI

\section{EcoRI}
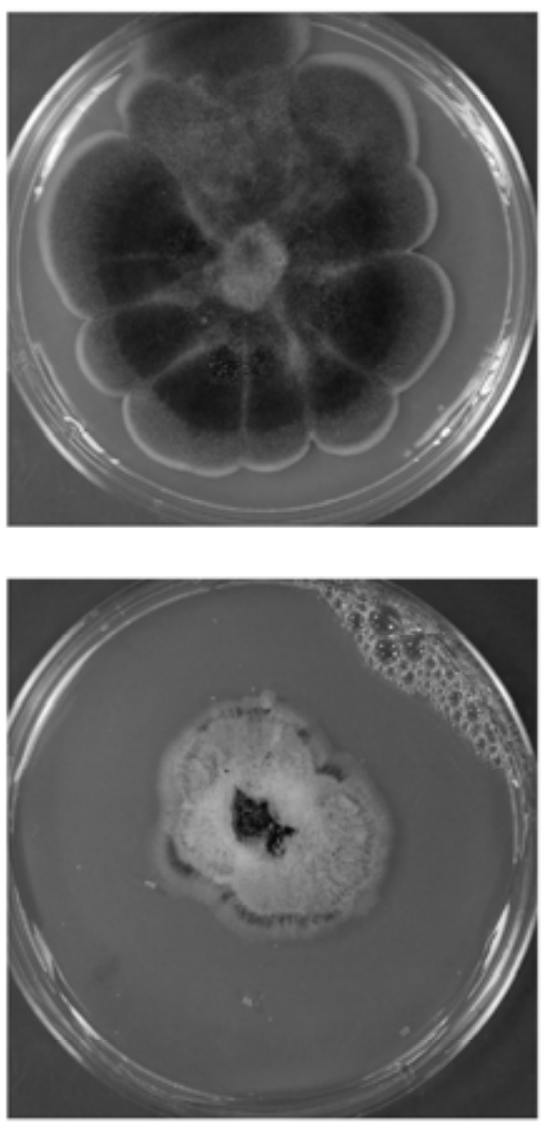

ClaBI hyg

\section{SnaBI/Not I}
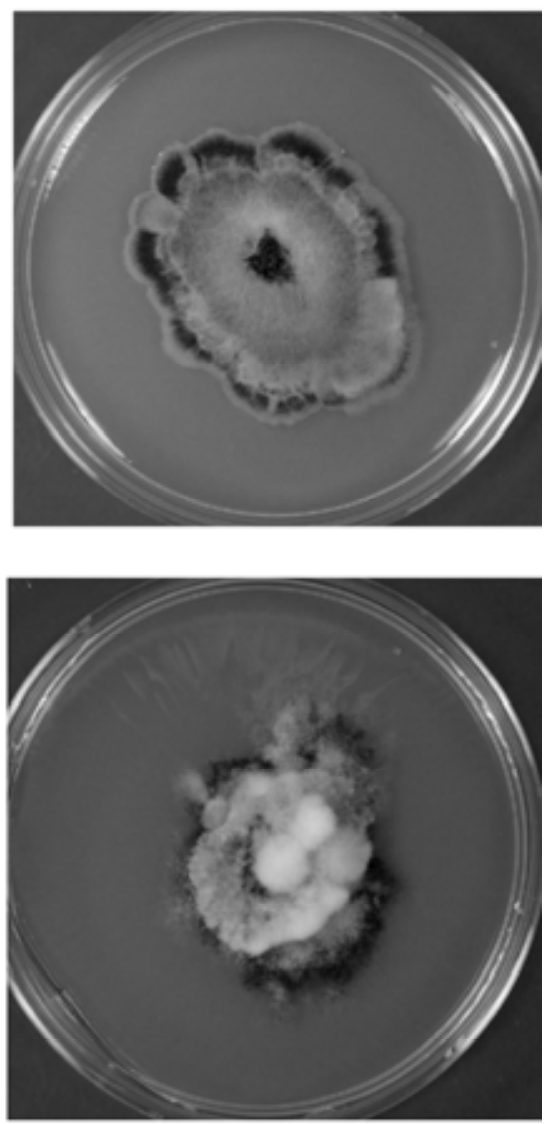

Strain A-9

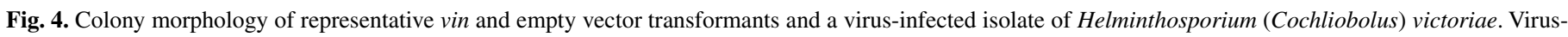

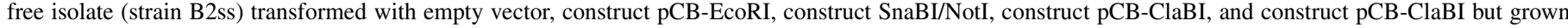

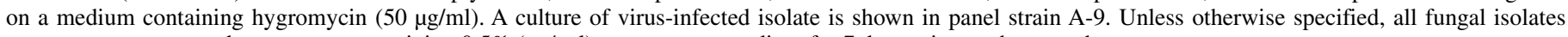
were grown on potato dextrose agar containing $0.5 \%$ (wt/vol) yeast extract medium for 7 days prior to photography. 


\section{DISCUSSION}

Present evidence suggests that overproduction of the broadspectrum antifungal protein victoriocin in culture filtrates of the virus-infected strain $H$. victoriae A-9 is correlated with virus infection because virus-free $H$. victoriae isolates secrete little or no victoriocin (2). We have previously presented evidence that victoriocin is encoded by a host gene, designated the vin gene, and predicted that it is expressed in vivo as a preprotoxin (preprovictoriocin). We envisioned, based on its structure, that the preprovictoriocin is processed by a signal peptidase and a kexinlike endopeptidase to generate the provictoriocin and the mature victoriocin, respectively (2). In the present study, we overexpressed the vin gene in a virus-free $H$. victoriae strain and clearly demonstrated the presence in the vin transformants of the preprovictoriocin and its post-translationally generated products, the provictoriocin and the mature victoriocin. Processing of the victoriocin preprotoxin requires eukaryotic host factors because no processing occurred in the in vitro translation system or in bacteria. Furthermore, culture filtrates of the vin transformants exhibited antifungal activity markedly higher than that revealed by the nontransformed virus-free strains. Moreover, transformation of the wild-type virus-infected $H$. victoriae strain with the vin gene resulted in still higher production of victoriocin and higher antifungal activity in the culture filtrates of the vin transformants compared with the virus-infected wild-type strain. Taken together, these results suggest that victoriocin is the primary protein responsible for the antifungal activity in culture filtrates of virus-infected $H$. victoriae isolates and that virus infection upregulates the expression of victoriocin.

The virus-infected diseased strain A-9, used in our study, shows typical disease symptoms of stunted and highly sectored colonies, aerial mycelial collapse, and swollen hyphae at the edge of colonies (7). Interestingly, some of the virus-free isolates transformed with the vin gene exhibited some features of disease symptoms, including moderate stunting and sectoring. It is not known, at present, whether victoriocin plays a direct or indirect role in disease development. Overproduction of victoriocin may give the slower-growing virus-infected fungal strains some competitive advantage by inhibiting the growth of aggressive fungi. The finding that victoriocin has little or no growth inhibition effects on $H$. victoriae isolates (2) rules out a direct role in disease

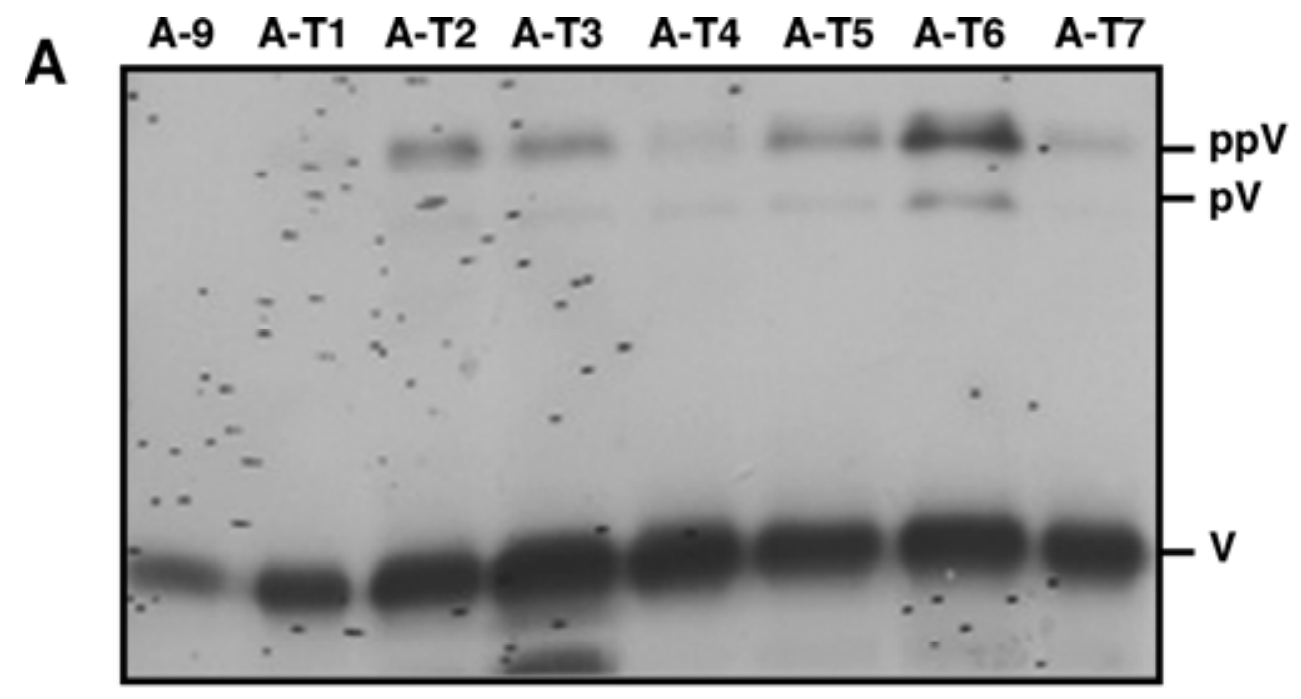

B-2 B-T1 B-T2 B-T3 B-T4 B-T5 B-T6 B-T12 B-T18 B-T20

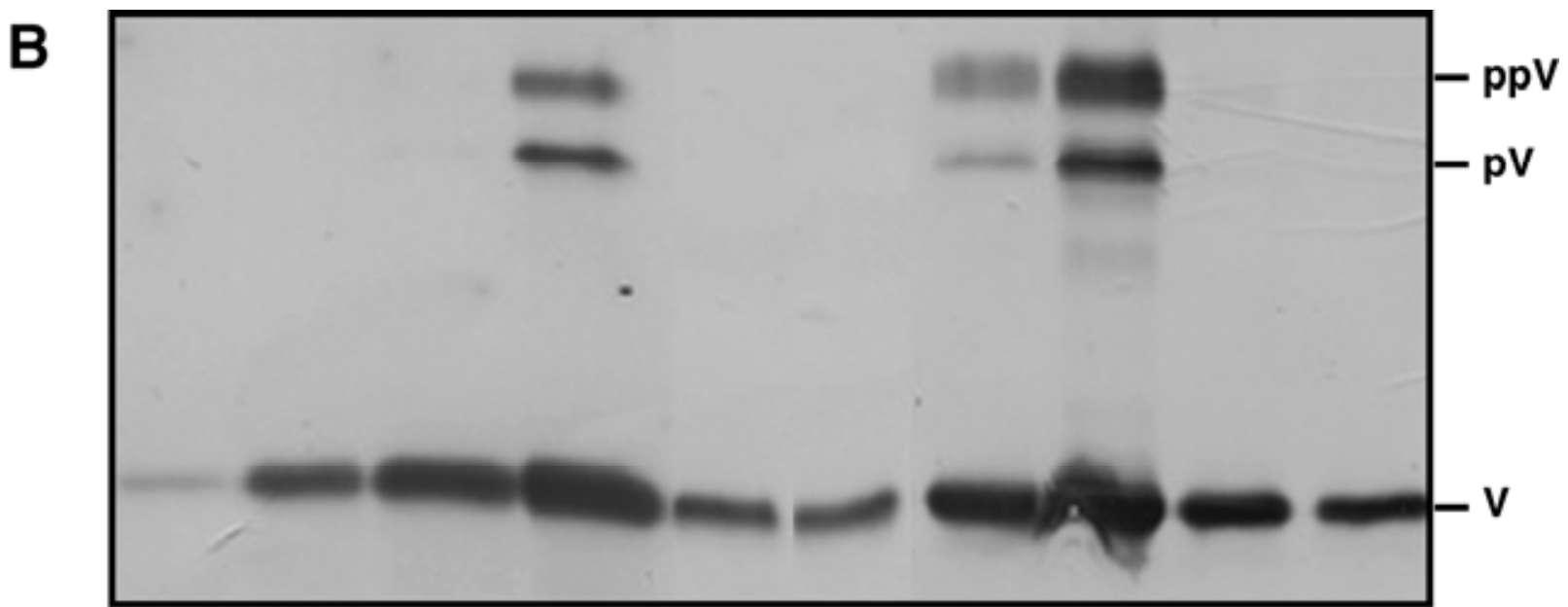

Fig. 5. Western blot analysis of virus-free and virus-infected Helminthosporium victoriae isolates transformed with the vin gene. A, Virus-infected strain A-9 and its vin-transformants, T1 through A-T7. B, Virus-free strain B-2 and its transformants, B-T1 through B-T6 and B-T-12, B-T18, and B-T20. 
development. Victoriocin may play an indirect role in disease development through the overexpression of the cell wall protein P30 (2). P30, which is overproduced in culture filtrates of virusinfected isolates and co-purifies with victoriocin, shares sequence similarity with PhiA cell wall proteins from several species of Aspergillus. PhiA, a homologue of $H$. victoriae P30 (2), is known to be overexpressed in Aspergillus nidulans in response to treatments with antifungal and antibacterial agents and may contribute to the resultant abnormal swollen hyphal morphology. The latter is reminiscent of some aspects of $H$. victoriae disease symptoms (7,11).

Another host factor that may play a role in disease development is the host gene $H v-p 68(13,14)$. It was previously demonstrated that $H v-p 68$ is upregulated as a result of virus infection. The Hvp68 protein belongs to the large family of FAD-dependent GMC oxidoreductases with 67 to $70 \%$ sequence identity to the alcohol oxidases of methylotrophic yeasts. Although the natural substrate for Hv-p68 is not known, the structurally similar alcohol oxidases are known to oxidize primary alcohols irreversibly to toxic aldehydes. Overexpression of $H v-p 68$ and resultant putative accumulation of toxic intermediates was proposed as a possible mechanism underlying the disease phenotype of virus-infected $H$. victoriae isolates. However, overproduction of Hv-p68 in virusfree fungal isolates resulted in a significant increase in colony growth and did not induce a disease phenotype (18). Hv-p68, which copurifies with viral dsRNA (mainly that of HvV145S), is a novel multifunctional protein with alcohol oxidase, protein kinase, and RNA-binding activities. The RNA-binding activity of Hv-p68 has been demonstrated by gel mobility shift and northwestern blot analysis $(13,14)$. Because dsRNA-binding proteins are known to sequester dsRNA and suppress antiviral host defense mechanisms, it is feasible that overexpression of the dsRNAbinding protein Hv-p68 may lead to the induction of the disease phenotype by suppressing host defense. This idea is consistent with the finding that overexpression of Hv-p68 led to enhancement in the accumulation of HvV145S dsRNA (18).

Regarding the viral factors that function as symptom determinants, our results to date indicate that HvV190S-CP is a major player in this regard (6) (unpublished data). Transformation of a normal virus-free fungal isolate with a full-length cDNA of Hv190SV dsRNA conferred a disease phenotype in some transformants. Symptom severity varied among the transformants from symptomless to severely stunted and highly sectored. Symptom severity correlated well with the level of viral capsid accumulation, with empty capsids accumulating to markedly higher levels in transformants exhibiting the disease phenotype. The role of the HvV145S in disease development, however, has yet to be elucidated (8).

In summary, the broad-spectrum antifungal protein victoriocin is encoded by the host vin gene, which is upregulated by virus infection. Like several other antifungal proteins, including the virally encoded killer proteins, victoriocin is expressed as a preprotoxin precursor. The marked similarities between some chromosomally encoded and virally encoded antifungal proteins suggest that the viral genes coding for these antifungal proteins were acquired by the virus from its eukaryotic host. We previously described the similarities between the chromosomally encoded victoriocin and the virally encoded zygocin (2). Victoriocin is believed to confer ecological advantage to its slow-growing host by inhibiting the growth of other fungi. Furthermore, up- regulation of the vin gene in the virus-infected isolates may indirectly contribute to the disease phenotype.

\section{ACKNOWLEDGMENTS}

This work was funded, in part, by grants (to S. A. Ghabrial) from the Kentucky Soybean Promotion Board and the Kentucky Tobacco Research and Development Center. This article is published with the approval of the Director of the Kentucky Agricultural Experiment Station (paper no. 10-12-029).

\section{LITERATURE CITED}

1. An, Z., Farman, M. L., Budde, A. D., Taura, S., and Leong, S. A. 1996. New cosmid vectors for library construction, chromosome walking and restriction mapping in filamentous fungi. Gene 176:93-96.

2. de Sá, P. B., Havens, W. M., and Ghabrial, S. A. 2010. Characterization of a novel broad-spectrum antifungal protein from virus-infected Helminthosporium (Cochliobolus) victoriae. Phytopathology 100:880-889.

3. Devereux, J., Haeberliy, P., and Smithies, O. 1984. A comprehensive set of sequence analysis programs for the VAX. Nucleic Acids Res. 12:387395.

4. Farman, M. 2001. Genome analysis in filamentous fungi. In: Molecular and Cellular Biology of Filamentous Fungi, A Practical Approach. N. Talbot, ed. Oxford University Press, Oxford.

5. Ghabrial, S. A. 1986. A transmissible disease of Helminthosporium victoriae: Evidence for a viral etiology. Pages 163-176 in: Fungal Virology. K. W. Buck, ed. CRC Press, Boca Raton, FL.

6. Ghabrial, S. A. 2008. Totiviruses. Pages 163-174 in: Encyclopedia of Virology, Vol. 5, 3rd ed. B. W. J. Mahy and M. H. V. Van Regenmortel, eds. Elsevier, Oxford.

7. Ghabrial, S. A., Sanderlin, R. S., and Calvert, L. A. 1979. Morphology and viruslike particle content of Helminthosporium victoriae colonies regenerated from protoplasts of normal and diseased isolates. Phytopathology 69:312-315.

8. Ghabrial, S. A., Soldevila, A. I., and W. M. Havens. 2002. Molecular genetics of the viruses infecting the plant pathogenic fungus Helminthosporium victoriae. Pages 213-236 in: Molecular Biology of DoubleStranded RNA: Concepts and Applications in Agriculture, Forestry and Medicine. S. Tavantzis, ed. CRC Press, Boca Raton, FL.

9. Marck, C. 1988. 'DNA Strider': A 'C' program for the fast analysis of DNA and protein sequences on the Apple Macintosh family of computers. Nucleic Acids Res. 16:1829-1836.

10. Osherov, N., and May, G. S. 1998. Optimization of protein extraction from Aspergillus nidulans for gel electrophoresis. Fungal Genet. Newsl. 45:38-40.

11. Psarros, E. E., and Lindberg, G. D. 1962. Morphology and respiration of diseased and normal Helminthosporium victoriae. Phytopathology 52:693-699.

12. Sambrook, J., and Russell, T. 2001. Molecular Cloning, A Laboratory Manual, 3rd ed. Cold Spring Harbor Laboratory, Cold Spring Harbor, NY.

13. Soldevilla, A., Havens, W. M., and Ghabrial, S. A. 2000. A cellular protein with RNA-binding activity co-purifies with viral dsRNA from mycovirusinfected Helminthosporium victoriae. Virology 272:183-190.

14. Soldevila, A. I., and Ghabrial, S. A. 2001. A novel alcohol oxidase/RNAbinding protein with affinity for mycovirus double-stranded RNA from the filamentous fungus Helminthosporium (Cochliobolus) victoriae. J. Biol. Chem. 276:4652-4661.

15. Sweigard, J., Chumley, F., Carroll, A., Farrall, L., and Valent, B. 1997 A series of vectors for fungal transformation. Fungal Genet. Newsl. 44:52-53.

16. Woo, S.-S, Jiang, J, Gill, B. S., Paterson, A. H., and Wing, R. A. 1994. Construction and characterization of a bacterial artificial chromosome library of Sorghum bicolor. Nucleic Acids. Res. 22:4922-4931.

17. Yoder, O. C. 1988. Cochliobolus heterostrophus, cause of Southern corn leaf blight. Adv. Plant Pathol. 6:93-112.

18. Zhao, T., Havens, W. M., and Ghabrial, S. A. 2006. Disease phenotype of virus-infected Helminthosporium victoriae is independent of overexpression of the cellular alcohol oxidase/RNA binding protein Hv-p68. Phytopathology 96:326-332. 